\title{
Purchase Intention towards Organic Food among Undergraduate Students
}

\author{
YATY SULAIMAN $^{1 *}$, WANNA PROMMANOP EH KAN ${ }^{2,}$ MARUF GBADEBO SALIMON ${ }^{3}$ \\ ${ }^{1,2,3}$ School of Business Management, College of Business Management, \\ Universiti Utara Malaysia, Kedah, \\ MALAYSIA
}

\begin{abstract}
Study examines factors influencing organic food purchase intention, precisely University Utara Malaysia students in organic food purchase. Planned Behaviour Theory model is widely used to predict user behaviour. Health awareness, environmental concerns, knowledge, and subjective norms are the variables involved to study purchase intentions to buy organic food. The targeted respondents selected for this study were 400 Bachelor Degree students. Questionnaire was designed and distributed to find the factors that influence purchase intention of organic food. All variables are found to be significant in this analysis.
\end{abstract}

Key-Words: - Purchase intentions, health awareness, environmental concerns, knowledge, subjective norms and price perception.

Received: April 29, 2020. Revised: September 30, 2020. Accepted: October 28, 2020.

Published: November 2, 2020.

\section{Introduction}

Today's people are more concerning on their diet and health. Moreover, human beings do not only care about their health but also care about the environment. Organic foods does not contain any synthetic participations such as non-natural pesticides and chemical fertilizers. Scientists claims that organic foods is good to consume because it does not have any side effects or risks in consumption. Many studies have proven that organic foods are high in vitamins and proteins needed by the body. Some relevant studies can be found in [1] regarding cholesterol in the human cell and younger generation with poorer nutrition dietary intake [2].

Organic food is being famous in the community. Consumers demand for organic food has increased and causing rapid growth sales in the organic food market. Current trends of consumers becoming more concerned on the value of food and health has increased the demand for organic food. Consumer purchase on organic food especially fruits and vegetables have nodded by the retailers and suppliers. Organic food becomes popular because it is safer, more nutritious and tastier compared to conventional food.
Lately, commercial advertisements of promoting the existence organic farming can also be seen on television. The Malaysian Agricultural Research and Development Institution (MARDI) found that there were more than $90 \%$ in 2008 and $95 \%$ in 2015 of Malaysians consumers aware that organic products are free from chemicals, good for health and it is natural (http://skor.mardi.gov.my/). Although the level of awareness has improved, there are still a few Malaysians who don't fully understand what organic food is about and how it's different compared to conventional foods [3]. [4] found that only people with higher income or people who are fine to pay in return for the product are buying organic products.

Organic agriculture is a combination production system of greatest environmental practices, with a good levels of biodiversity, natural preservation resources. It also provides high animal welfare as well as high quality products. Organic farming has developed rapidly around the world in recent years due to technological advances and increasing number of consumer dissatisfaction with conventional food. Even though the demand for organic food increased, the agriculture for organic food products is relatively still slow. DirectorGeneral of the Malaysian Agricultural Research and Development Institute (MARDI), Datuk Dr Sharif Haron has mentioned that the development 
of organic agriculture in this country were slightly slower compared with other Asian countries.

Price of organic fruits and vegetables are double the price of ordinary goods due to the farming methods of organic is different. Price issue sometimes stops consumers from purchasing and being more sensitive to product prices [5]. Overall thought of local organic products is still low. Experts are required to spread information to consumers regarding benefits of organic food and put more effort to supervise and ensure local organic food follows the procedures and standards. Therefore, this research was conducted to identify important factors influencing consumer perceptions towards organic food, and what makes them to buy organic food. Findings of this study will guide the marketing and production of organic food to cooperate. Factors influencing consumers to consume organic food will make marketers to recognise consumer opinion of organic food. Marketer have put their great efforts in offering diversified organic food products (e.g., vegetables, grains and meat) as well as expanding their distribution network [6]. Apparently, several authors assert that organic food retailers need to develop and implement effective marketing practices to support consumers' decision-making process on purchasing organic food [7].

\section{Literature Review}

Organic foods does not contain pesticides such as synthetic materials or sewage sludge made fertilizers; biochemistry; or radioactivity radiation. Before a product can be labelled "organic" certification, it must be approved by the relevant Government who inspects the farms where food are grown. Organic food by farmers emphasizes on renewable resources. Conservation of land and water improves the quality of the environment for future generations. Farmers needs to follow every organic standard regulations required by the United States Department of Agriculture

(USDA). (http://www.organic.org/home/faq).

Commercial organic farming is still at infancy in Malaysia. Establishment of commercial organic farms in Malaysia was introduced by Non-Profit Organizations (NPOs) who cared about food quality [8]. Organic farming in Malaysia uses compost from agriculture. There are people also eats organic from the forest or naturally grown such as wild mushrooms and bamboo shoots.

[9] found that organically grown fruits, vegetables and nuts comprise more nutrients, including vitamin $\mathrm{C}$, iron, magnesium and phosphorus, with less pesticides compared to plants grown with pesticide use and synthetic steel. Foods with more nutrients and fewer harmful substances are healthy and those who consume it will be healthier. Basically, organic farming does not destroy the ecosystem as it is not polluted by chemicals [9]. Many knows that organic foods are grown on organic principles and does not have harmful herbicides and pesticides. Facts shows that this food has health benefits because it is without chemical residues and pathogens as well as nutritional values are higher than other conventional foods [10].

\subsection{Purchase Intentions}

In general, consumers who has favourable attitudes towards the purchasing organic food tend to make actual purchases [11]. [12] says intention significantly predicts an individual's actual behaviour for the future. It is the attitudes and behaviours that is required to implement the behaviour [13]. As an example, intention to purchase certain products needs an assessment of the other product in the market [14]. A person's intention to buy a product will be the decision and reason why they wants to buy that particular brand. [15] further explains that consumer's purpose to buy a particular product not only by his/her own attitude but also depending on the future decisions when they have the intention to buy other brands. There are many factors motivates purchase behaviour associated with organic food include values, environmental concern, knowledge, perceived quality, emotions, health consciousness on nutrition, food taste and food safety [16].

Consumers trust that organic food is good for them and this positive attitude greatly influenced their intention to buy those [17]. Previous study by [18], says health issues encouraged consumers to buy organic food. A past research by [19], identified health issues has strongly influence consumers intention of buying organic food compared to environmental factors. [20] have also identified that consumer's wants to buy organic food when the price is not high. Meanwhile, [21] said environmental issues and health awareness 
may have positive purchasing intentions towards organic food. [22] found significant relationship among consumers' attitude and buyers 'intentions towards organic food.

\subsection{Health Awareness and Purchase Intentions}

Health is a balance movement of energy evolving the in and out (input and output) in an equilibrium (enabling growth). It carries the ability to survive (Wikipedia). [23] refers health awareness to how an individual pay attention to their health. Consumers believe that environmental friendly products are good for their health also that may help to preserve the environment. Consumers who are health-conscious are those who prefers to have good a health with healthy actions [24]. Health issues are one of the key factors influencing consumers to buy organic food products. [25] emphasize on health issues being the main driver of organic food purchase. [26] argues that consumers' positive attitude to consume organic food without fear and suspicion derived from the belief that organic foods are good for health. Food safety concern makes people worried about pesticide residues contained in food as well as about food scares [27]. [28] also found that consumers' ready to buy organic food with premium price because they are concerning about food safety. Vietnamese believes that unsafe food practices puts their health at risk (Nguyen). According to [21] perceived value and health awareness are significant predictors of Malaysian consumers buying intentions.

H1: Health awareness significantly influence purchase intentions for organic foods.

\subsection{Environmental Concern and Purchase Intentions}

Environment concern is about the responsibility to keep the environment clean and free from pollution to preserve and improve environment quality. Environment concern is one of the key factors that drive consumers in buying organic food. Some research shows that organic production able to reduce the danger to the environment. Lately, consumers are becoming more aware in protecting the environment through which ever method they can do so. [29] and [30] found that consumers who wish to protect and maintain the environment may have a positive attitude towards the intention of buying organic food. Environmental awareness refers to every actions which are significant to environment, such as the use of environmental resources. Moreover, environmental awareness can be described through certain behaviours [31]. [32] found that environmental friendly or organic products have moderately influence the purchasing intentions of consumers in Penang. Based on a study by [33], there is a positive relationship between purchase intentions is significant towards organic food. This is because care for the environment has influence them to buy organic food.

$\mathrm{H} 2$ : Environmental concerns significantly influence purchase intentions for organic food.

\subsection{Knowledge and Purchase Intentions}

Consumer knowledge is about information that remains in their memory. Information stored in a person's memory will affect them in making a purchase decision. Users will generally act based on the knowledge they are aware of. Knowledge changes the perception of the user whether be it in a positive or negative attitude. The more information a person has, the more likely the person will ensure whether it's either a good or bad products. [34] stated that knowledge of the environment will help to transform a person thinking into an environmentally sensitive person. [35] have found that knowledge on properties of organic foods can be the key to buy the product. Knowledge about organic food is one of the key factor influencing purchasing organic food. [36] claim that when consumers are having more knowledge about organic food, they will be more likely has a positive attitude towards purchasing them. In particular, it is related to subjective knowledge influencing consumer attitudes than objective knowledge [37]. According to [38] information about organic foods in market has a huge influence on consumers' subjective knowledge. Consumer's awareness of organic food can be obtained from different sources such as social media, social networks, and reports from ecological groups, advertising and many more. Apart from that, experience is also an important factor influencing consumer understanding of organic food. As an example, consumers who has a positive attitudes towards organic food from their past experiences believe that buying organic food is important and a good choice [39]. 
In addition, knowledge will also affect consumer confidence level. When there is lack of knowledge in new information, there will be a low level of trust for users to receive the new information. Dissatisfied consumers with the newly received information will get back to the information they received previously on the product [40] Therefore, it can be said that when consumers have higher knowledge related to organic products then their tendency to buy organic food is also high.

H3: Knowledge significantly influence purchase intentions of organic food.

\subsection{Purchase Intentions and Subjective Norms}

Subjective norms is perception of social pressure influencing whether behaviour should be done or not [41]. An individual's perception is controlled by his / her normative belief whether or not to present a certain form of behaviour [41]. Normative belief depends on the strength of motivation to adhere to the practice of social norms. [42], found that subjective norms will not be able to predict the individuals' level of desire with high locus of internal control or individuals with strong orientation. The most important social influencers are parents, friends, role models, mentors and social networks. Subjective norms are one of the significant factors influencing consumers 'intentions to buy organic food. Particularly, it is more common in countries with higher social interaction where people tend to follow referral groups, leaders who then influence them towards a particular behaviour. Significant relationship of subjective norms and intention to purchase organic food has been found in several studies [30] [20] [29] [43]. Subjective norms are not only affecting behaviour, it also affects attitude. [22] found significant relationship between subjective norms and consumer intentions in purchasing. According to [44], subjective norms have little effect of Thai and Cambodian consumers towards purchasing organic products. These findings indicates that these consumers feels that their purchasing intentions for organic food are not much influenced by other individuals such as family members, friends on social media, but it solely depends on their own personal motivation. Subjective norms are not significant with purchasing intention of students in a college in Malaysia to consume organic food products. It means that subjective norms are not being an important factor influencing college students' purpose to consume organic food products.

H4: Subjective norms significantly influence purchasing intentions of organic foods.

\subsection{Purchase Intentions and Price Perception}

Price refers to the value paid by consumers in exchange for the product or service sold. American Marketing Association defines that price ratio is the total money required to get a certain amount of product or services (Marketingpower.com). Price is the evaluation to how much consumer able to pay to get a product or services. Price may influence consumers' purchase intentions of organic products. According to [45] premium price is an extra amount paid for a particular product compared to the normal price and this can indicate the willingness of consumers to pay for organic products.

According to [45] there are consumers who have the notion that organic food is much more costly than conventional food. Although environmental concerns encourages consumers' decision, relatively high prices can also prevent them from buying as they are more sensitive towards price. [46] said higher price of organic food is one of the main reason stopping consumer's intention to buy organic food. The importance of price considered as one of the main influencing factor to buy organic food [47]. Moreover, [20] suggest that price determine consumer intention in purchasing organic food. Furthermore, if there is a business that can offer prices and quality for organic products equalling to conventional products prices, then the consumers will be more likely to protect the environment with higher purchasing intentions for environmental friendly products [48]

H5: Price perception significantly influence purchase intentions of organic food.

\section{Methodology}

\subsection{Research Framework}

Planned Behaviour Theory provides the basis of the model of this study. Planned Behaviour Theory and previous empirical studies give us 
the basis of a framework model. This theory provides three main variables in attitudes, subjective norms and perceptions of behavioural control.

All three variables affect intention directly, and then intention in turn affects actual behaviour. These three variables become determinants of behavioural intentions and are then broken down into several key beliefs by [49] through a model of the breakdown of Planned Behaviour Theory. Thus, attitudes are broken down into several beliefs namely health awareness, environmental concerns, and knowledge of organic foods. While price perception is chosen to represent the perception of behaviour control [50]. Following the model shows a conceptual framework of this study.

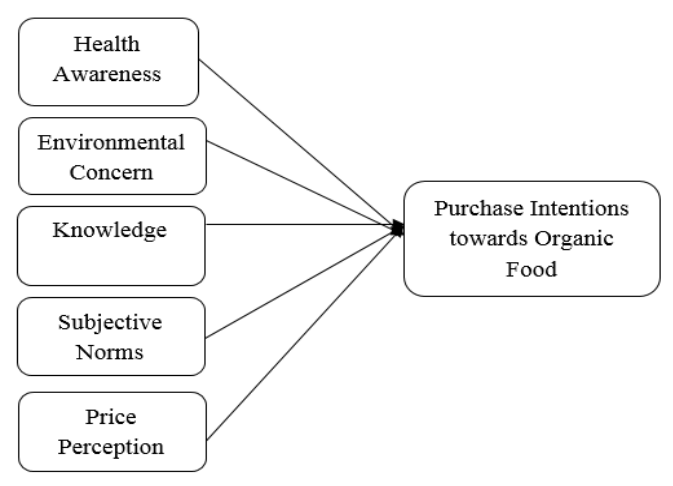

Figure 1: Research Framework

\subsection{Research Design}

[52] says that research design consist of conditions for data collection and data analysis. Research design involves work plan and details needs to be done to complete the project. Research design will be able to provide evidence to answer questions at an early stage. Obtaining applicable information consists of stating the type of evidence to answer research questions, test theories, evaluate a program or describe some phenomena accurately.

\subsection{Data Collection Methods}

Study used primary and secondary data. Primary data is an original data organized and available for the public. Primary data is consistent, accurate and unbiased as it is from direct experience. Various methods can be used to get information. Primary data of this study were collected through questionnaires relevant to the topic. Questionnaire of this research has two main parts namely demographic profile and factors that influence the purchase intention of organic food products. All data obtained from the target respondents will be analysed to draw conclusions. Questionnaire is easier to reach the respondents. [52] mentioned secondary data is collected from existing research studies to obtain different data from original data set. Secondary data will be available in written, typed or electronic form. Books, articles, journals, information from the internet and newspapers were the sources used for this study. Secondary data is important as it can prove and support statements and avoid misinformation. Secondary data also helps in contributing a better and more accurate research studies.

\subsection{Population and Sampling}

\subsubsection{Target Population}

Objective of this study is to determine factors influencing intention to purchase organic food of Universiti Utara Malaysia undergraduate students. According to the latest data by Registrar's Department, total number of students for Bachelor's Degree program is 16,715 students. Based on the [53] sample size of 375 respondents is considered sufficient to represent the total number of Bachelor Degree students, UUM. For an effective data, 400 respondents were designated to answer the questionnaires.

\subsection{Sampling Techniques}

Probability sampling i.e. each Bachelor Degree student, UUM was selected and has the same opportunity to enter the selection process. This type of sample is easy to access and get feedback from respondents.

\subsection{Sampling Size}

[54], stated that sample size charged is within 30 to 500 respondents. Study's population was determined as Bachelor's Degree student of UUM. Based on Table 1, the total sample size required is 375. To obtain more effective data 400 respondents were being selected. Out of 400 sets of questionnaires distributed, only 389 sets of questionnaires was able to applied while 5 sets of questionnaires were not returned and 4 were 
rejected because respondents did not answer according to the required specifications.

Table 1. Sample Size According to Krejcie \& Morgan (1970)

\begin{tabular}{cc}
\hline Population Size (N) & Sample Size (S) \\
\hline 10,000 & 370 \\
15,000 & 375 \\
20,000 & 377 \\
30,000 & 379 \\
40,000 & 380 \\
\hline
\end{tabular}

Source: Krejcie \& Morgan (1970)

\section{Findings}

\subsection{Respondents Gender}

Table 1. Gender

\begin{tabular}{llll}
\hline Features & Details & Frequency & Percentage \\
\hline Gender & Male & 141 & 36.2 \\
& Female & 248 & 63.8 \\
Total & & 389 & 100 \\
\hline
\end{tabular}

Table 4.22 above shows that the total number of respondents involved which is 389 people answering this questionnaire. The percentage of male respondents is $36.2 \%$ while the percentage of female respondents is $63.8 \%$.

\subsection{Mean and Standard Deviation}

Table 2. Mean and Standard Deviation

\begin{tabular}{|l|l|l|}
\hline Variable & Min & Standard deviation \\
\hline Purchase Intent & 3.5478 & .29397 \\
Health Awareness & 3.5815 & .33192 \\
Environmental Awareness & 3.4589 & .34731 \\
Knowledge & 3.7265 & .29896 \\
Subjective Norms & 3.1861 & .28186 \\
Price Perception & 3.3630 & .35241 \\
\hline
\end{tabular}

Mean and standard deviation is to achieve results for the measurement of central tendency and measurement of the propagation of dependent variables and independent variables. Results of study shows that knowledge has the highest mean value of 3.7265 and subjective norm is the lowest of 3.1861. While the highest standard deviation is price perception which are 0.35241 and the lowest is subjective norm which is 0.28186 .

\subsection{Pearson Correlation Analysis}

[55] said that when the significant value is less than 0.01 in the correlation test, there will be a relationship between the two variables. In addition, value (r) is a correlation coefficient indicating the strength of the relationship between the two variables [55].

Table 3. Pearson Correlation Analysis Value

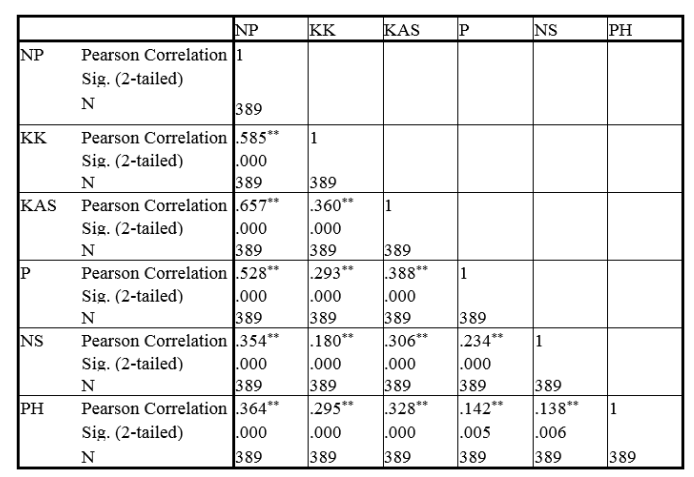

**. Correlation is significant at the 0.01 level (2tailed).

Table 3 shows significant value for all variables is 0.000 and this causes all hypotheses to be accepted. While the correlation value between the dependent variables (purchase intention) and the independent variables (health awareness, environmental concerns, knowledge, subjective norms and price perceptions) is between 0.354 to 0.657 . Overall, this table also shows the positive relationship between dependent variable and all independent variables.

\subsection{Multiple Regressions Analysis}

Table 4. Model Summary

\begin{tabular}{|l|l|l|l|l|}
\hline Model & $\mathrm{R}$ & R Square & Adjusted R Square & $\begin{array}{l}\text { Std. Error of the } \\
\text { Estimate }\end{array}$ \\
\hline 1 & $.747^{\mathrm{a}}$ & .558 & .552 & .19682 \\
\hline
\end{tabular}

a. Predicators: (Constant), PH, NS, P, KK, KAS

Based on Table 4, the value of $\mathrm{R}^{2}$ is 0.558 . This indicates that $55.8 \%$ of the variance in purchase intentions is predictable from independent variables (health awareness, environmental concerns, knowledge, subjective norms and price perceptions).

Table 5. ANOVA ${ }^{a}$ 


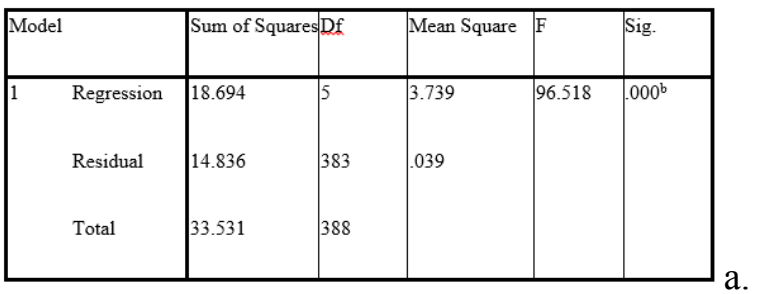

Dependent Variable: NP

b. Predictors: (Constant), PH, NS, P, KK, KAS

Based on Table 5, the F-value is 96.518 and the significance level $p=0.000$. In conclusion, there is a significant effect of independent variables (health awareness, environmental concerns, knowledge, subjective norms and price perceptions) on dependent variables (consumer purchasing intentions).

Table 6. Coefficients

\begin{tabular}{|c|c|c|c|c|c|}
\hline \multirow[b]{2}{*}{ Model } & \multicolumn{2}{|c|}{ Unstandardized Coefficients } & \multirow{2}{*}{\begin{tabular}{|l}
$\begin{array}{l}\text { Standardized } \\
\text { Coefficients }\end{array}$ \\
Bcta
\end{tabular}} & \multirow[b]{2}{*}{$t$} & \multirow[b]{2}{*}{ sig. } \\
\hline & $B$ & Stt. Eror & & & \\
\hline $\begin{array}{l}\text { (Constant) } \\
\end{array}$ & 175 & .177 & & .988 & 324 \\
\hline KK & 215 & $\mid .033$ & .243 & 6.508 & .000 \\
\hline KAS & 364 & .034 & .430 & 10.554 & .000 \\
\hline P & .167 & .037 & .170 & 4.557 & .000 \\
\hline Ns & .129 & .038 & .124 & 3.425 & .001 \\
\hline PH & .092 & .031 & .111 & 3.010 & .003 \\
\hline
\end{tabular}

a. Dependent Variable: NP

Purchase intention $=0.175+0.215$ (health awareness) +0.364 (Environmental anxiety) + 0.167 (Knowledge) +0.129 (Subjective norms) + 0.092 (Price Perception).

According to the above equation, the regression coefficient of health awareness on organic food is 0.215 . This means that consumer intention to buy organic food will increase 0.215 units when health awareness of organic food increases 1 unit while others remain. Furthermore, the regression coefficient for environmental concerns was 0.364. When consumers purchase intentions increases at 0.364 units, environmental concerns increases at 1 unit and others remain. In addition, the knowledge regression coefficient is 0.167 . When consumers purchasing intentions for organic food increases at 0.167 as knowledge increases 1 unit and others remain. Moreover, the regression coefficient of subjective norm is 0.129 . This shows consumer purchasing intentions for organic food increase by 0.129 when the subjective norm increases by 1 unit and the rest remains. Finally, regression coefficient for price perception is 0.092 . This means that consumers' buying intentions for organic food will increase 0.092 units when the price perception increases 1 unit while others remain. Among the five independent variables, environmental concerns have strongest influence towards consumer purchasing intentions for organic foods where the beta standard equals 0.430 . Thus, environmental concern for organic food is the most important predictor of consumer purchasing intentions for organic food and is followed by health awareness on organic food (0.243), knowledge (0.170), subjective norms $(0.124)$, and lastly is price perception (0.111).

\subsection{Summary of Findings}

Table 7. Hypothesis Findings

\begin{tabular}{|l|l|l|}
\hline Hypothesis & $\begin{array}{l}\text { Significant } \\
\text { Value }\end{array}$ & Result \\
\hline $\begin{array}{l}\text { H1: Health awareness significantly influence purchase intentions } \\
\text { of organic foods. }\end{array}$ & $\mathrm{p}=0.000$ & Accepted \\
\hline $\begin{array}{l}\text { H2: Environmental concerns significantly influence purchasing } \\
\text { intentions towards Organic Food. }\end{array}$ & $\mathrm{p}=0.000$ & Accepted \\
\hline $\begin{array}{l}\text { H3: Knowledge significantly influence purchase intention of } \\
\text { organic food. }\end{array}$ & $\mathrm{p}=0.000$ & Accepted \\
\hline $\begin{array}{l}\text { H4: Subjective norms significantly influence purchasing } \\
\text { intentions of organic foods. }\end{array}$ & $\mathrm{p}=0.001$ & Accepted \\
\hline $\begin{array}{l}\text { H5: Price perception significantly influence purchase intent on } \\
\text { organic food. }\end{array}$ & $\mathrm{p}=0.003$ & Accepted \\
\hline
\end{tabular}

\section{Conclusion}

The growth of organic food market in the future depends on consumers demand. This study aims to reveal that health awareness, environmental concerns, knowledge, subjective norms and price perceptions are those factors that influencing consumer purchasing intentions towards organic food. Past research concludes that consumer's interest to purchase organic food vary by country.

A positive health-conscious consumers develop a positive attitude towards organic food because of its benefits that can help in maintaining healthy health. This is because organic foods contain natural ingredients and good for the health than conventional foods with no side effects or risks.

Research will be able to educate organic food producers and marketers with a better understanding of consumers buying power of organic food. An important factor contributing to this study is that the intention to buy organic food highly depend with health, environmental, 
knowledge, subjective norms and price perceptions. With this, practitioners may use the results as a basis to develop a strategic marketing plan on the most effective communication messages to promote organic food that significantly affect consumer behaviour and perception. Practitioners may also apply the knowledge to improve marketing techniques to enhance their sales of organic food.

This study able to guide the marketing and production of organic food in cooperating with their consumers needs. There is an urgent need to determine the reasons behind consumers 'intention to buy organic food because the increasing demand for organic food is distressing the industry while the supply for organic food in Malaysia is lesser than the demand. Future studies should emphasis more on other factors that affect consumer purchasing intentions on organic food with longer target segments to obtain accurate results.

\section{Acknowledgement}

Yaty Sulaiman is Associate Professor of Marketing, School of Business Management, College of Business, Universiti Utara Malaysia 06010 Sintok, Kedah, Malaysia. The author would like to thank The Ministry of Higher Education (MOHE) for granting this research under the Fundamental Research Grant Scheme (FRGS) and Research Innovation Management Centre (RIMC) Universiti Utara Malaysia. This article is under FRGS grant research.

\section{References}

[1] Anatoly V. Sikorsky, Menizibeya O. Welcome, Vladimir A. Pereverzev, Lipid Metabolism and Functions of PituitaryThyroid Axis in Children with Arterial Hypotension, International Journal of Biology and Biomedical Engineering, pp. 124-130, Volume 12, 2018.

[2] Dehong Ding and Sisi Zhu, Evidence based Intervention to Prevent Anemia Among Women of Reproductive Age Group in Developing Countries; Review, International Journal of Biology and Biomedical Engineering, pp. 58-62, Volume 13, 2019.

[3] Zeinab, S. S. \& Seyedeh, M. S. (2012). The main factors influencing purchase behavior of organic products in Malaysia.
Interdisciplinary Journal of Contemporary Research in Business, 4(1).

[4] Ahmad, S. N. B., \& Juhdi, N. (2010). Organic Food: A Study on Demographic Characteristicand Factors Influencing Purchase Intentions among Consumers in Klang Valley, Malaysia. International Journal of Business and Management, 5(2), 105-118

[5] Synovate Survey. (2012). Reveals Latest Green Habit and Consumption across the World.www.Iposs-

nacom/newspolls/pressrelease.aspx?id.Retri eved $4 / 10 / 2013$

[6] Le V.H., Mai T.T.C., Lobo A., Nguyen N., Phan H.L. Effective segmentation of organic food consumers in Vietnam using foodrelated lifestyles. Sustainability. 2019;11:1237.

[7] Vietnam News The Organic Food Market Is Getting More and More Vibrant. [(Accessed on 25th October 2020)]; 2018 Available online: $\quad \mathrm{http}: / /$ vietnamnews.vn/brandinfo/482472/the-organic-food-market-isgetting-more-and-morevibrant.html\#tFkilfeLgF2TklZV.99.

[8] Partap, T. (2010). Emerging Organic Farming Sector in Asia: A Synthesis of Challenges and Opportunities. In Organic Agriculture and Agribusiness: Innovation and Fundamentals. Tokyo: Asian Productivity Organization.

[9] Willer, H. \& Kilcher, L. (Eds.) (2011): The World of Organic Agriculture. Statistics and Emerging Trends 2011. IFOAM, Bonn, \& FiBL, Frick.

[10] Andre L. (2004), The Benefits of Organic Food: A Growing Body of Scientific Evidence, The Voice of Eco-Agriculture, 34 (5), pp. 702-720.

[11] Meyer-Höfer M., Olea-Jaik E., Padilla-Bravo C.A., Spiller A. Mature and emerging organic markets: Modelling consumer attitude and behaviour with partial least square approach. J. Food Prod. Mark. 2015;21:626-653. doi: 10.1080/10454446.2014.949971.

[12] Tan, T. H. (2013). Use of Structural Equation Modeling to Predict the Intention to. Purchase Green and Sustainable Homes in Malaysia. Asian Social Science, 9(10), 181191

[13] Ramayah, T., Lee, J.W., and Mohamad, O. (2010). Green product purchase intention: some insights from a developing country. 
Resources, Conservation and Recycling 54 (12), 1419-1427.

[14] Teng, L., \& Laroche, M. (2007). Building and testing models of consumer purchase intention in competitive and multicultural environments. Journal of Business Research, 60(3), 260-268

[15] Porter, M. E. (1974). Consumer behavior, retailer power and market performance in consumer goods industries. The Review of Economics and Statistics, 56(4), 419-436.

[16] Grunert S.C., Juhl H.J. Values, environmental attitudes, and buying of organic foods. J. Econ. Psychol. 1995; 16:3962. doi: 10.1016/0167-4870(94)00034-8

[17] Suprapto, B., Wijaya, T., 2012. Intentions of Indonesian consumers on buying organic food. Int. J. Trade Econ. Financ. 3 (2), 114 119.

[18] Schifferstein, H. N., \& Oude Ophuis, P. A. (1998). Health-related determinants of organic food consumption in the Netherlands. Food Quality and Preference, 9(3), 119133.

[19] Magnusson, Arvola, Hursti. A, et. al, (2001). Attitudes towards organic foods among Swedish consumers. British Food Journal 103(3):209-227

[20] Lodorfos, G. N. \& Dennis, J. (2008).

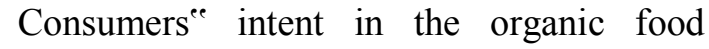
market. Journal of Food Products Marketing, 14(2):17-38.

[21] Salleh, M. M., Ali, S. M., Harun, E. H., Jalil, M. A., \& Shaharudin, M. R. (2010). Consumer's peception and purchase intention toward organic food products: Exploring attitude among academician. Canadian Social Science, 6(6), 119-129.

[22] Tarkiainen, A., \& Sundqvist, S. (2005) Subjective norms, attitudes and intentions of Finnish consumers in buying organic food. British Food Journal, 107 (11), 808-822.

[23] Iversen, A. C., \& Kraft, P. (2006). Does socio-economic status and health consciousness influence how women respond to health related messages in media?. Health Education Research, 21(5), 601-610.

[24] Ling-Yu, M. W. \& Shang-Hui, L. 2013. A Study on The Relationship Amidst Health Consciousness, Ecological Affect, And Purchase Intention Of Green Production. International Journal of Organizational Innovation, 5, 124-137.

[25] Yin, S., Wu, L., Du, L., \& Chen, M. (2010). Consumers' purchase intention of organic food in China. Journal of the Science of Food and Agriculture, 90, 1361-1367

[26] Thogersen, J.,\& Zhou, Y. 2012, "Chinese Consumers' Adoption of a 'Green' Innovation - The Case of Organic Food", Journal of Marketing Management, pp. 313333.

[27] Pham T.H., Nguyen T.N., Phan T.T.H., Nguyen N.T. Evaluating the purchase behaviour of organic food by young consumers in an emerging market economy. J. Strateg. Mark. 2018:1-17. doi: 10.1080/0965254X.2018.1447984

[28] Mohamed, M.A., Chymis, A. \& Shelaby, A.A. (2012). Determinants of organic food consumption in Egypt. International Journal of Economics and Business Modeling, Vol.3(3), pp.183-191.

[29] Vermeir, I. \& Verbeke, W. (2006). Sustainable food consumption: Exploring the consumer "attitude-behavioral intention" gap. Journal of Agriculture and Environmental Ethics, 19(2):169-194

[30] Chen, Y.S.; Chang, C.H. Enhance green purchase intentions: The roles of green perceived value, green perceived risk, and green trust. Manag. Decis. 2012, 50, 502520.

[31] Sharma, K. \& Bansal, M. (2013): Environmental Consciousness, Its Antecedents and Behavioural Outcome. Journal of Indian Business Research, Emerald Group Publishing Limited. Vol 5 (3) 198-214.

[32] Ling, C. Y. (2013). Consumers Purchase Intention of Green Products: An Investigation of the Drivers and Moderating Variable, Elixir. International Journal Marketing Management, 57A. 14503-14509.

[33] Werner, J., \& Alvensleben, R.V. (2011).Consumer Attitudes towards Organic Food in Germany (F.R.). Symposium on Horticultural Economics, VIII (155).

[34] Kaiser, F.G., \& Schultz, P.W. (2009). The attitude-behavior relationship: A test of three models of the moderating role of behavioral difficulty. Journal of Applied Social Psychology, 39, 186-207.

[35] Anderson J.C., Wachenheim C.J., \& Lesch W.C., (2006), Perception of Genetic Modified and Organic Foods and Process, AgBioForum, 9(3), pp. 180-194.

[36] Stobbelaar, D.J., Casimir, G., Borghuis, J., Marks, I., Meijer, L. \& Zebeda, S. (2007), "Adolescents' attitudes towards organic 
food: a survey of 15- to 16-year old school children", International Journal of Consumer Studies, Vol. 31, pp. 349-56.

[37] Ellen, P. (1994). Do we know what we need to know? Objective and subjective effects on pro-ecological behaviors. Journal of Business Research, 30(1), 43-52.

[38] Gracia A, De Magistris T. (2007), Organic food product purchase behaviour:a pilot [40] Aertsens, J., Mondelaers, K., Verbeke, W., Buysse, J., \& Huylenbroeck, G. The influence of subjective and objective knowledge on attitude, motivations and consumptions of organic food. Br. Food J.2011;113:1353-1378.

[41] Ajzen, I., \& Madden, T. J. (1986). Prediction of goal directed behavior: Attitudes, intentions, and perceived behavioral control. Journal of Experimental Social Psychology, 22, 453474.

[42] Krueger, N., Reilly, M. \& Carsrud, A. (2000). Competing Models of Entrepreneurial Intentions. Journal of business Venturing, 15, 411-432.

[43] Phuah Kit Teng, Golnaz Rezai, Zainalabidin Mohamed, \& Shamsudin, M. N. (2011). Consumers' Intention to Purchase Green Foods in Malaysia. International Conference on Innovation, Management and Service, vol.14 (2011).

[44] Pomsanam, P. Napompech, K. \& Suwanmaeneepong, S. (2014). An exploratory study of the organic food purchase intention among ThaiCambodian Cross- Border Consumers. Asian Journal of Applied Science, 7(5):294-305

[45] Numraktrakul, P., Ngarmyarn, A. \& Panichpathom, S. (2011). Factors Affecting Green Housing Purchase, 111.

[46] Zhen J. S. S. \& Mansori, S. (2012). Young Female Motivation for Purchase of Organic. Food in Malaysia. International Journal of Contemporary Business Studies, 3(5), 61-72.

[47] Ahmad, S. N. B., \& Juhdi, N. (2010). Organic Food: A Study on Demographic Characteristics and Factors Influencing Purchase Intentions among Consumers in Klang Valley, Malaysia. International study for urban consumers in the South of Italy Spanish Journal of Agricultural Research 5(4), pp. 439-451.

[39] Magnusson M.K., Arvola A., Hursti U.K.K., Åberg L., Sjödén P.O. Attitudes towards organic foods among swedish consumers. Br. Food J. 2001;103:209-227. doi: $10.1108 / 0007070011038675$

Journal of Business and Management, 5(2), 105-118.

[48] Ali, A. \& Ahmad, I. (2012). Environmental Friendly Products: Factors that Influence the Green Purchase Intention of Pakistan Consumers. Pakistan Journal of Engineering Technology Science, 2(1) 84-117

[49] Taylor, S. and Todd, P. A. (1995). Understanding Information Technology Usage: A Test of Competing Models. Information Systems Research, 6, 144176.

[50] Zeinab, S. S. \& Seyedeh, M. S. (2012). The main factors influencing purchase behavior of organic products in Malaysia. Interdisciplinary Journal of Contemporary Research in Business, 4(1).

[51] Logasakthi, K., \& Rajagopal, K. (2013). A Sudy on employee health, safety and welfare measures of chemical industry in the view of salem region. International Journal of Research in Business Management (IJRBM), 1(1), 1-10.

[52] Smith, E., (2008). Using Secondary Data in Educational and Social Research. Open University Press.

[53] Krejcie, R. V, \& Morgan, D. W. (1970). Determining sample size for research activities. Educational and Psychological Measurement, 30, 607-610.

[54] Saiful, (2011). Importance or quality sample size. May 5, 2016, from http://www.uniteforsight.org/globalhealth-university/importance-of-qualitysample-size

[55] Pallant, J. (2005). SPSS survival manual: A step by step guide to data analysis using SPSS for Windows (version 12). Buckingham, UK: Open University Press.

\section{Creative Commons Attribution License 4.0 (Attribution 4.0 International, CC BY 4.0)}

This article is published under the terms of the Creative Commons Attribution License 4.0

https://creativecommons.org/licenses/by/4.0/deed.en_US 